\title{
İdiyopatik myelofibrozis tanılı olguda adaptif splenik radyoterapi
}

\author{
Adaptive splenic radiation in a case of idiopathic myelofibrosis \\ Ayfer Ay*, Mehmet Fuat Eren \\ Radyasyon Onkolojisi Anabilim Dalı (Yrd. Doç. Dr. A. Ay, Yrd. Doç. Dr. M. F. Eren), \\ Cumhuriyet Üniversitesi Tip Fakültesi, TR-58140 Sivas
}

\begin{abstract}
Özet
İdiyopatik myelofibrosis kronik myeloproliferatif bir hastalıktır. Kronik myeloproliferatif hastalıklar myeloid hücre büyümesi ile ilişkili klonal kök hücre bozukluklarıdır. Kemik iliği yetersizliğine bağlı görülen ekstramedüller hematopoez ve artmış eritropoez sonucu masif splenomegali gelişir, bu da anemi ve abdominal rahatsızlığa yol açarak morbiditeye sebep olur. Splenik radyoterapi masif splenomegaliye bağlı görülen abdominal ağrı, anemi ve trombositopeni gibi semptomları palyasyon amacıyla önerilmektedir. Bu çalışmada idiyopatik myelofibrozis tanısı ile takip edilen 59 yaşındaki erkek olgu değerlendirildi. Masif splenomegaliye bağlı narkotik analjezik kullanımı gerektiren şiddetli ağrı, hipersplenizmin neden olduğu ciddi trombositopeni ve tekrarlayan transfüzyon ihtiyacı sonucu palyasyon amacı ile haftada 2 fraksiyon toplamda 6 fraksiyon olacak şekilde haftalık artan dozlarda splenik RT uygulandı. Tedavi sonrası olgunun abdominal ağrısında \%100 palyasyon sağlandığı görüldü. Splenik RT, semptomatik splenomegalinin palyatif tedavisinde etkin bir tedavi modalitesi olarak göz önünde bulundurulmalıdır.
\end{abstract}

Anahtar sözcükler: İdiyopatik myelofibrozis, splenomegali, splenik radyoterapi

\begin{abstract}
Idiopathic myelofibrosis is a chronic myeloproliferative disorder. Chronic myeloprolipherative disorders are clonal stem cell disorders associated with myeloid cell growth . Extramedullary hematopoiesis in the bone marrow deficiency and increased erythropoiesis resultin massive splenomegaly which then lead to anemia and abdominal discomfort which are major causes of morbidity in these cases. Splenic radiotherapy is recommended for palliation of symptoms such as abdominal pain, anemia and thrombocytopenia due to massive splenomegaly. In this study, a 59year-old male patient with a diagnosis of idiopathic myelofibrosis was evaluated. Splenic radiotherapy was applied to him in 2 fractions per week with increasing doses for a total of 6 fractions as he had massive splenomegaly, severe pain requiring narcotic analgesic use, and had repeated need for transfusion caused by severe thrombocytopenia due to hypersplenism His abdominal pain palliation was achieved by $100 \%$ after treatment. . Splenic radiotherapy should be considered as an effective treatment modality for palliative treatment of symptomatic splenomegaly.
\end{abstract}

Keywords: Idiopathic myelofibrosis, splenomegaly, splenic radiotherapy

Geliş tarihi/Received: 14 Mayıs 2012; Kabul tarihi/Accepted: 16 Mayıs 2012

\section{*İletişim adresi:}

Dr. Ayfer Ay, Radyasyon Onkolojisi Anabilim Dalı, Cumhuriyet Üniversitesi Tıp Fakültesi, TR58140 Sivas. E-posta: drayferay@gmail.com

\section{Giriş}

İdiyopatik myelofibrosis (IMF) kronik myeloproliferatif bir hastalıktır. Kronik myeloproliferatif hastalıklar myeloid hücre büyümesi ile ilişkili klonal kök hücre 
bozukluklarıdır [1]. Kronik myeloid lösemi (KML), polisitemia vera (PV) ve esansiyel trombositemi (ET) de kronik myeloproliferatif hastalık olarak bilinmektedir. IMF sıkl1kla 50 yaşın üzerindeki hastalarda karşımıza çıkar. Hastalığın çok erken dönemleri hariç en sık laboratuvar bulgusu anemidir. Kemik iliği yetersizliğine bağlı görülen ekstramedüller hematopoez ve artmış eritropoez sonucu masif splenomegali gelişir bu da anemi ve abdominal rahatsızlığa yol açarak morbiditeye sebep olur [2]. IMF'de küratif tedaviler sınırlıdır olsada Allojenik kök hücre transplantasyonu, kötü prognostik faktörlere sahip genç olgularda yüz güldürücü sonuçlar vermektedir [3]. Ancak IMF hala allojeneik kemik iliği transplantasyonundan yarar görmeyen yaşlı hastaların hastalığıdır. Bu durumlarda sadece standart ve palyatif tedaviler söz konusudur. Yeni gelişen palyatif tedavi yaklaşımları olarak anemide; eritrosit transfüzyonu ve androjen tedavisi, trombositoz, lökositoz ve hipermetabolik semptomların kontrolü için de kemoterapötik ajanlar (tirozin kinaz inhibitörleri; imatinib, dasatinip, nilotinip gibi) kullanılmaktadır [4]. Masif splenomegalide splenektomi veya splenik palyatif radyoterapi bir başka tedavi seçeneğidir. Splenik radyoterapi (RT) masif splenomegaliye bağlı görülen abdominal ağrı, anemi ve trombositopeni gibi semptomları palyasyon amaciyla önerilmektedir. Mekanizması tam olarak bilinmemekle birlikte direkt hücre ölümü, immun modülasyon, sitokin indüksiyonu veya yüksek dozlarda 'radyoterapötik splenektomi' gibi değişik mekanizmalar üzerinden etkili olduğu düşünülmektedir [5]. İdiyopatik myelofibrozis nedeniyle 2 yıldır takip edilen ve takipleri sırasında anemiye bağlı tekrarlayan eritrosit transfüzyonları almaktayken gelişen; abdominal ağrı ile kendini gösteren ilerleyici splenomegali vede derinleşen trombositopeniye bağlı tekrarlayan kanamaları olan olguya palyasyon amaçlı splenik radyoterapi uygulandı. Abdominal ağrı ve splenomegalide tam regresyon elde edilen, eritrosit transfüzyon ihtiyacı ortadan kalkan olgu bu yönleri ile sunulmaya uygun bulundu.

\section{Olgu sunumu}

İdiyopatik myelofibrozis tanısı ile takip edilen 59 yaşındaki erkek olgu iki yıl önce halsizlik şikayeti ile doktora başvurmuştur. Bu tarihte yapılan rutin tetkiklerden tam kan sayımında pansitopeni tespit edilmesi üzere yapılan kemik iliği biyopsisinde; myelofibrotik değişiklik ve hiposellüler kemik iliği tespit edilmiştir. Abdomen ultrasonografisinde dalak normalden büyük ve uzun boyutu $20 \mathrm{~cm}$ olarak splenomegali ile uyumlu olduğu değerlendirilmiştir. Tanıdan 12 ay sonra sübjektif olarak karın boşluğu sol tarafinda dolgunluk hissi başlayan olgunun takipleri sırasındaki abdomen ultrasonografisinde dalak normalden büyük ve uzun boyutu $28 \mathrm{~cm}$ olarak rapor edilmiştir. Masif splenomegaliye bağlı narkotik analjezik kullanımı gerektiren şiddetli ağrı, hipersplenizmin neden olduğu ciddi trombositopeni ve tekrarlayan transfüzyon ihtiyacı sonucu palyasyon amacı ile splenik RT için kliniğimize refere edilmiştir. RT süresince her fraksiyon öncesi tam kan sayımı ve haftada bir, böbrek ve karaciğer fonksiyon testleri ile kontrol edildi. RT planlaması öncesinde, RT bitiminde ve RT sonrası 1. ay, 2.ay ve 3.ay olmak üzere aynı radyolog tarafından ultrasonografi ile dalağın boyutlarındaki değişiklik takip edildi. Olgudan gerekli yazılı onamlar alınarak ve olguya detaylı bilgi verilerek haftalık BT simülasyon çekilip yeni konformal plan oluşturularak $6 \mathrm{MV}$ foton enerjili kullanılarak lineer hızlandırıcı cihazı ile haftada 2 fraksiyon toplamda 6 fraksiyon olacak şekilde haftalık artan dozlarda RT uygulandı. Splenik RT şemasında ilk hafta iki fraksiyon 0.5 Gy'lik fraksiyonları, ikinci hafta 2 fraksiyon 0,75 Gy'lik fraksiyonları ve üçüncü hafta 2 fraksiyon 1 Gy’lik fraksiyonları içeriyordu. RT süresince dalak boyutlarındaki küçülme, her hafta çekilen BT simülasyona göre yeniden RT planı yapılarak değerlendirildi. Olgunun subjektif ağrı şikayetleri tedavi öncesinde, her RT fraksiyonu sonrasında, tedavi tamamlandığında ve üç aylık kontrollerinde 100 üzerinden değerlendirildi. Tedavi başlangıcında ağrı 100 olarak belirtilirken ilk hafta sonrası 100, ikinci hafta sonrası 50 ve tedavi bitimi ve sonrasindaki 3 aylık aylık kontrollerinde 0 olarak değerlendirildi. Olgunun RT sonrası üçüncü ay kontrolünde aynı radyolog tarafindan yapılan üst abdomen ultrasonografisinde dalak normalden büyük, uzun boyutu $18 \mathrm{~cm}$ idi. Yapılan fizik muayenede dalak palpe edilemiyordu. Bu kontrolündeki tam kan 
sayımında kırmızı küre 3,5*10 $12 / \mathrm{L}$, hemoglobin düzeyi $9 \mathrm{~g} / \mathrm{dL}$, hemotokrit $\% 29$ ve trombosit 43000/uL idi. Olgu, ağrı yakınması tümüyle düzelmiş, transfüzyon ihtiyacı azalmış olarak üç aydır takip edilmektedir.

\section{Tartışma}

IMF kemik iliği fibrozisi, extramedüller hematopoez ve kanda dolaşan periferik lökoeritroblastik kan hücreleri ile karakterize bir hematopoetik kök hücre hastalığıdır. IMF tanılı hastaların klasik klinik bulguları artmış kırmızı küre, beyaz küre ve trombosit sayısı, yüksek hematokrit düzeyleri ve splenomegali veya kombinasyonu şeklinde görülebilmektedir [1,5]. Ana fiziksel bulgu splenomegalidir ancak kontrol edilmesi zor bir semptomatik bulgudur. Hastalar çoğunlukla yaşlı olduklarından, palyatif tedavi modaliteleri uygulanır. Splenik RT uzun yıllar çeşitli hematolojik malignitelerin tedavisinde kullanılmıştır. Splenik RT 20.yüzyılın başlarında tek etkili antineoplastik tedavi olarak lösemi tedavisinde kullanılmıştır, fakat antineoplastik ilaçların kullanılmaya başlanmasıyla birlikte RT endikasyonu, splenomegalisi olan hastaların palyasyonu ile sınırlı kalmıştır. Splenik RT'nin temel amacı splenomegaliye sekonder gelişen pansitopeni, karın ağrısı ve bası bulguları gibi semptomları düzeltmektir [6]. Mekanizması tam olarak bilinmemekle birlikte splenik RT dalağın retiküloendotelyel sistemdeki görevini azaltır, lenfosit sayısını düşürerek splenomegali gerilemesine ve anemi ile trombositopeniden kismen sorumlu olan $\mathrm{T}$ supresor lenfositlerin yok olmasina yol açar [5]. Splenik radyoterapide primer endikasyon splenomegaliye bağlı oluşan ağrı yakınması olup bizim olgumuz da şiddetli ağrı yakınması ile başvurmuştur. Tedavi edici bir metod olarak radyoterapiye ilişkin raporlar literatürde nadirdir. IMF'nin splenik RT modaliteleri ile ilgili çok az veri vardır. Literatürler incelendiğinde tedavi etkinliğini değerlendiren birkaç çalışmaya rastlanmaktadır [5-10]. Paulino and Reddy [7] splenik RT sonuçlarını değerlendirdikleri çalışmada lenfoproliferatif ve kronik myeloproliferatif hastalık tanısı ile izlenen hastalardaki splenomegalinin \%60 olguda, abdominal ağrının ise olguların \%90'ında azaldığını gözlemlemişlerdir. Bu çalışmanın sonucunda splenik RT'nin kısa süreli de olsa splenomegalinin neden olduğu ağrı palyasyonunda etkili olduğu gösterilmiştir. Fraksiyon şemasının önemini gösteren bir başka çalışmada ise Wienmann ve ark. [5]'nın kronik myeloproliferatif hastalıkta günlük tek doz 0,25 Gy'lik dozlarda toplam 1-9 Gy doz verilerek yaptıkları splenik radyoterapi ile olguların semptomlarında belirgin düzelme olduğunu bildirmişlerdir. Hipofraksiyonasyon şemasının incelendiği bir başka çalışmada ise McFarland ve ark. [8] konvansiyonel tedaviden farklı olarak hipofraksiyone tedavinin etkinliğini incelemişlerdir. Bu şema ile haftada iki fraksiyon olacak şekilde toplam üç haftada altı fraksiyon uygulamışlardır. Günlük verilen fraksiyon dozları, her hafta için sırasıyla 0,5 Gy, 0,75 Gy ve 1 Gy olacak şekilde belirlenmiş ve sonuçta hematolojik malignitelerde, splenik RT ile \%50-90 oranında küçülme olduğunu; radyoterapiden 4 ay sonra bile ağrı azalmasının ve dalak boyutunun küçülmesinin $\% 40$ azaldığını, splenik RT'de hipofraksiyon şemasının uygulanmasının daha düşük yan etki profili ile düzelme sağladığını belirtmiş̧lerdir. Son yıllarda tedavi protokolü ile ilgili yapılan çalışmalarda splenik RT'de günlük dozun 0,5-1 Gy, haftada 2 veya 3 fraksiyonda toplam 3,5-6 Gy olmasının daha uygun olduğu belirtilmiştir [7, 9, 10] Bizim çalışmamızda da İMF'li olgunun splenik RT şeması bu şekilde oluşturuldu. Tedavi sonrası olgunun abdominal ağrısında \%100 palyasyon sağlandığı görüldü. Yanıt oranımız literatürler ile uyumlu bulundu. Ayrıca literatürlerde belirtilen sitopeni, nötropeni gibi ciddi hematolojik yan etkiler bizim olgumuzda görülmedi.

Splenik RT, splenektominin riskli olduğu yaşlı olgularda, ilaç tedavisini tolere edemeyen olgularda ve semptomatik splenomegalinin palyatif tedavisinde hem efektif olmasi hem de düşük toksisite profili ve daha düşük maliyeti nedeniyle etkin bir tedavi modalitesi olarak göz önünde bulundurulmalıdır. Tekrarlanabilir bir tedavi şeklidir. Bununla birlikte splenik RT'nin etkinlik ve yan etkilerinin karşılaştırıldığ 1 olgu sayısının yüksek olduğu klinik çalışmalar gerekmektedir. 


\section{Kaynaklar}

1. Weinstein IM. Idiopathic myelofibrosis: historical review, diagnosis and management. Blood Rev 1991; 5: 98.

2. Tefferi A, Spivak JL. Polycythemia vera: Scientific advances and current practice. Semin Hematol 2005; 42: 206-20.

3. Guardiola P, Esperou H, Cazals-Hatem D, Ifrah N, Jouet JP, Buzyn A, Sutton L, Gratecos N, Tilly $\mathrm{H}$, Lioure B, Gluckman E. Allogeneic bone marrow transplantation for agnogenic myeloid metaplasia. French Society of Bone Marrow Transplantation. Br J Haematol 1997; 98: 1004.

4. Chen SW, Hwang WS, Tsao CJ, Liu HS, Huang GC. Hydroxyurea and splenic irradiation-induced tumour lysis syndrome: a case report and review of the literature. J Clin Pharm Ther 2005; 30: 623-5.

5. Weinmann $\mathrm{M}$, Becker $\mathrm{G}$, Einsele $\mathrm{H}$, Bamberg $\mathrm{M}$. Clinical indications and biological mechanisms of splenic irradiation in chronic leukaemias and myeloproliferative disorders. Radiother Oncol 2001; 58: 235-46.

6. Slanina J, Vondraczek A, Wannenmacher M. Symptomatic irradiation therapy of the spleen in advanced osteomyelosclerosis. Dtsch Med Wochenschr 1986; 111: 1144-50.

7. Paulino AC, Reddy SP. Splenic irradiation in the palliation of patients with lymphoproliferative and myeloproliferative disorders. Am J Hosp Palliat Care 1996; 13: 32-5.

8. McFarland JT, Kuzma C, Millard FE, Johnstone PA. Palliative irradiation of the spleen. Am J Clin Oncol 2003; 26: 178-83.

9. Parmentier C, Charbord P, Tibi M, Tubiana M. Splenic irradiation in myelofibrosis. Clinical findings and ferrokinetics. Int J Radiat Oncol Biol Phys 1977; 2: 1075.

10. Cihan YB, Yokuş O, Mutlu H. Kronik miyeloproliferatif hastalığılan yaşlılarda gelişen semptomatik splenomegalide palyatif radyoterapinin rolü. Turkish Journal of Geriatrics 2012; 15: 34-9. 